\title{
Sizing of Solar Water Pumping System for Irrigation of Oil Palm Plantation in Abia State
}

\author{
Idorenyin Markson ${ }^{1}$, Simeon Ozuomba, ${ }^{2, *}$, Iniobong Edifon Abasi-Obot ${ }^{3}$ \\ ${ }^{1}$ Department of Mechanical Engineering, University of Uyo, Nigeria \\ ${ }^{2}$ Department of Electrical/Electronic and Computer Engineering, University of Uyo, Nigeria \\ ${ }^{3}$ Department of Electrical/Electronic Engineering, Akwa Ibom State University, Nigeria
}

Copyright@2019 by authors, all rights reserved. Authors agree that this article remains permanently open access under the terms of the Creative Commons Attribution License 4.0 International License

\begin{abstract}
In this paper, sizing of solar water pumping system for irrigation of oil palm plantation in Abia State, Nigeria was presented. The relevant meteorological data for the case study site were obtained from the NASA website. The daily water requirements for the oil palm trees were determined and the pumping system was simulated using PVSyst software. According to the results, the annual water demand for the oil palm plantation was $14636 \mathrm{~m}^{3}$ but the pumping system was able to supply about $12251 \mathrm{~m}^{3}$ of water which was equivalent to a missing water of about $16.3 \%$ per year. Based on the missing water, the month of February was identified as the critical month with the lowest water supply to the plants. Furthermore, when the rainwater capture on the palm plantation was also considered along with the solar pumped water, it was found that in the month of February, the grown-up yielding oil palm trees can still get their required maximum daily water requirement of 200 liters per day while the older palm trees can get their daily water requirement of 338.55 liters/day. In essence, the shortfalls in the irrigation water pumping system can be supplied by the rainwater. In all, the solar-powered pumping system and the rainwater capture in the oil palm plantation can effectively meet the water need of the oil palm trees in the case study plantation.
\end{abstract}

Keywords Solar Energy, Water Pump, River-to-Storage Pump, PVSyst Software, Renewable Energy

\section{Introduction}

According to experts, adequate water supply is very essential for proper growth and high yield of oil palm trees $[1,2,3,4,5]$. Consequently, oil palm tree is one of the plants that are widely planted in the Southern part of Nigeria, which is a rain forest zone. However, the Southern part of Nigeria also has dry season, which lasts for about six months in every year. As such, the due to inadequate water supply, most of the palm trees do not give acceptable yield [6, 7]. In order to boost the oil palm annual yield, irrigation was considered and implemented for a pilot oil palm plantation in Abia state.

Specifically, the sizing of the solar powered water pump for oil palm plantation drip irrigation system is presented $[8,9,10,11]$. The system is simulated using PVSyst software. The focus of the system sizing is to ensure that the daily water demand of oil palm trees is met in all the months of the year. As such, after the simulation, the critical month is identified and the water supplied by the irrigation system is evaluated. The relevant system and site parameters are presented, along with the mathematical equations and procedures for the simulation and analysis.

Generally, in Nigeria, the peak period for oil palm yield is in the months of March to June; the period falls within the rainy season in the Southern part of Nigeria where the oil palm trees are planted in commercial quantity. Consequently, the palm oil price in this period drops to its lowest level. However, during the dry season, particularly from October till January, the oil palm yield drops significantly and the palm oil price rises to more than two times the price in March to June. As such, this study became necessary to seek for ways to boost the oil palm yield even in the dry season. Moreover, a study by Mrudula [21] showed that drip irrigation is financially viable for oil palm plantation. Besides, studies have shown that there is high oil palm yield per hectare through drip irrigation method; some studies estimates the increase in yield to about 30 to $40 \%$ [21,22]. Furthermore, drip irrigation is more efficient and has faster return on investment than the other irrigation approaches [21]. Since the palm oil price in the off-peak period increases by more than $100 \%$ above the peak period price, any slight increase in oil palm yield in the off-peak period will attract much financial benefits to the investors. 


\section{The Meteorological Data of the Case Study Site}

The location of the case study oil palm plantation is in Isuikwuato local government area of Abia state and it has the following geo-coordinate values; latitude of 5.838904, longitude of 7.480773 and altitude of $84 \mathrm{~m}$. The geo-coordinate parameters are used in PVSyst software to obtain the monthly average solar radiations per day and temperature of the site from the NASA website [12], as shown in Figure 1.

The Peak Sun Hour (PSH) version of the monthly average solar radiation per day and temperature for the case study site is shown in Figure 2. According to Figure 2, the case study site has an annual average daily PSH of 4.7 hours per day. This value is used in the calculation of the water flow rate and the daily volume of water to be pumped for the irrigation system.

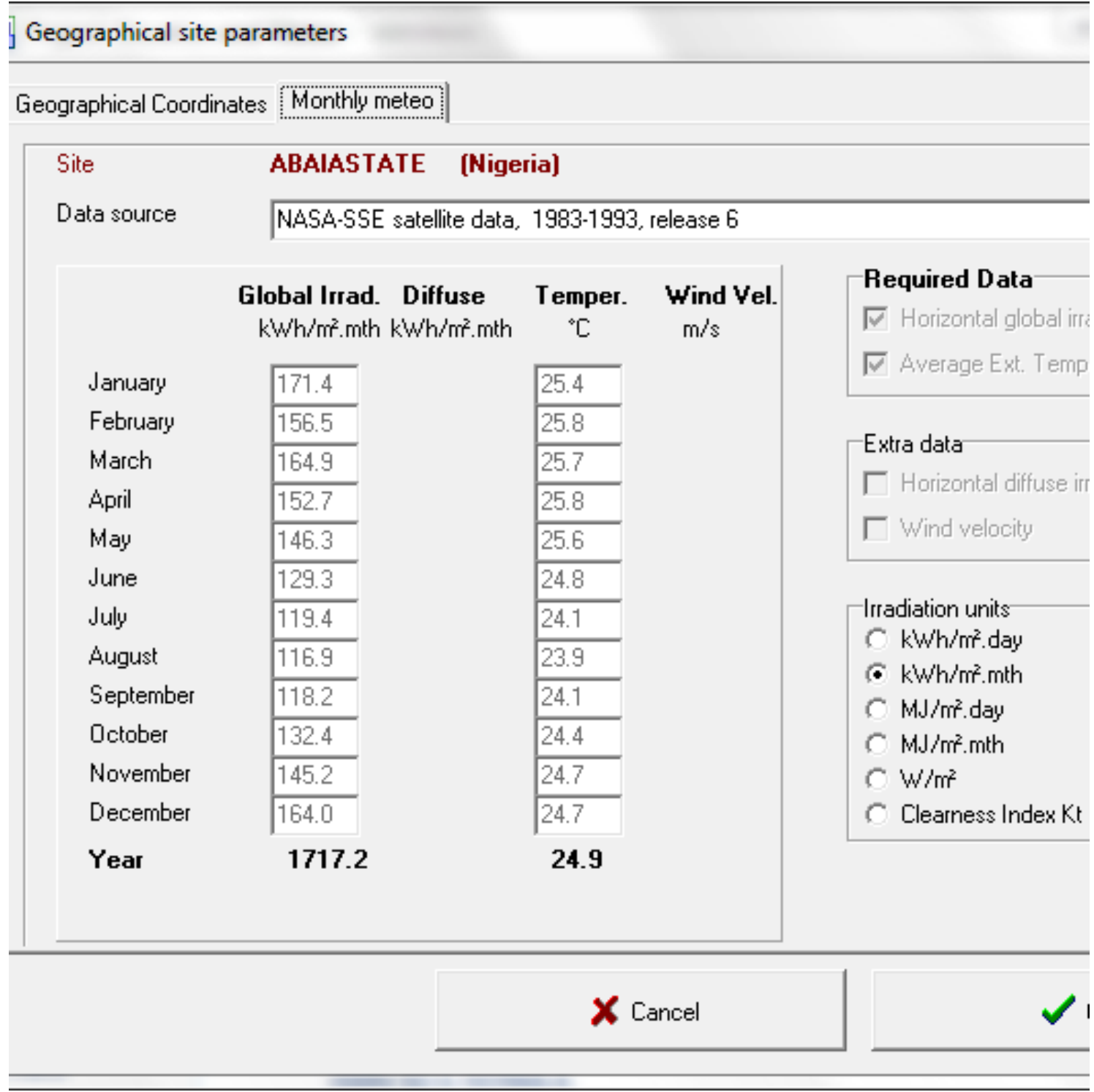

Figure 1. Monthly average solar radiation per day and temperature for the case study site 


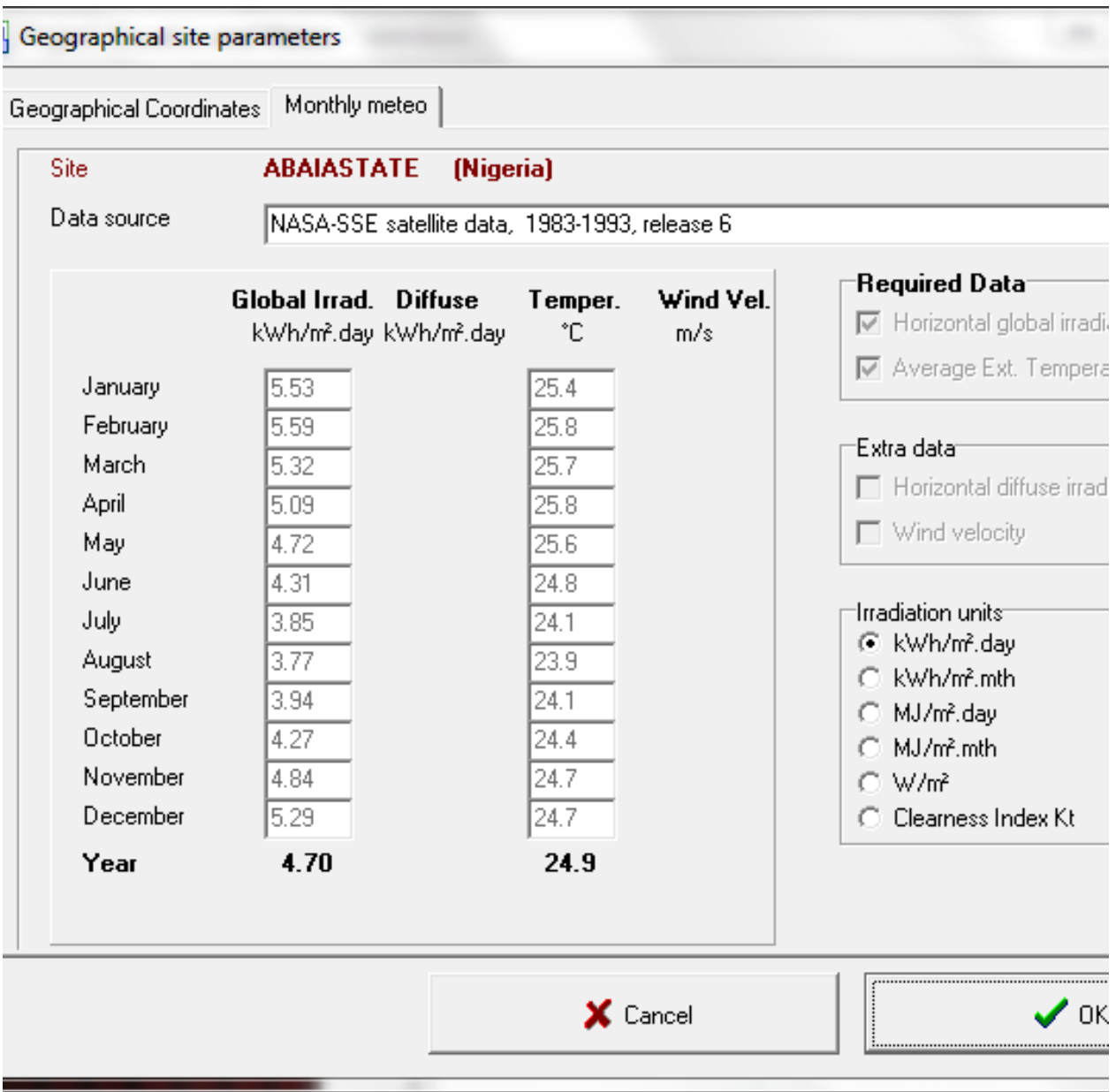

Figure 2. The Peak Sun Hour (PSH) version of the monthly average solar radiation per day and temperature for the case study site

\section{The Daily Water Requirement of the Oil Palm Tree Plantation}

The daily water demand and size of the storage tank for the irrigation of the palm plantation are determined from published data on oil palm plantation and the data on the case study plantation. Particularly, data on plant density, daily water requirement of the plant and the irrigation water flow rate are used in this paper to determine the daily water requirement for the case study oil palm plantation. According to available literature, an optimum plant density of 143 oil palm per hectare is widely reported [13, 14, 15]. Also, according to experts, grown-up yielding oil palm tree of three (3) years and above require about 150-200 liters/day of water; however, during the hot season, older oil palm trees may need about 300 to 350 liters of water per day $[16,17,18]$.

As regards irrigation of palm oil plantation, the drip irrigation method is usually recommended $[17,18]$. For oil palm, a typical dripper water discharge rate of 8 liters/hour is used; hence, in 4.7 hours (that is, the annual average PSH of the site) about 37.6 liters of irrigation water will be generated per dripper $[17,18,19]$. Considering that older plants may need about 300 to 300 liters per day, a total of 8 drippers is adopted which gives a total daily water supply of 300.8 liters per day. The analytical expressions used to arrive at the daily water demand per hectare of palm tree are given as follows:

Number of drippers used in the drip irrigation system per palm tree, $n_{d r}=8$

Water discharge rate for each dipper used in the drip irrigation system, $r_{d r}=8$ liters/hour

Number of hours per day irrigation water will be applied is denoted as $h i_{d r}$. In this paper, for the solar pumping system, there will be no backup battery. As such, the solar pump will be powered solely by the solar power. Accordingly, the annual average daily PSH of the case study site is used as the daily average solar power supply hours per day, From Figure 2, the annual average daily $\mathrm{PSH}$ is 4.7 hours per day. Hence, for the irrigation system, $h i_{d r}=$ Annual Average Daily PSH =

4.7 hours per day. The daily volume of water demand per palm tree per day is $V w_{p d p t}$ where;

$$
\begin{aligned}
V w_{p d p t}= & \left(n_{d r}\right)\left(r_{d r}\right)\left(h i_{d r}\right)=(8)(8)(5)= \\
& \text { 300.8 liters per day }
\end{aligned}
$$

Although during the hot season, the older palm trees may need up to 350 liters per day, however, a moderate daily 
water volume of 300.8 liters per day is adopted in this paper. This is because it is noted that the palm plantation will also have grown-up yielding oil palm trees which demand about 150-200 liters of water per day per hectare. The case study oil palm plantation spans 1.04 hectares of land at plant density of 130 plants per hectare which amounts to a total of 136 oil palm trees. Therefore, the total daily water requirement for the case study plantation is denoted as $V w_{p d P}$ where;

$$
V w_{p d P}=V w_{p d p t}\left(n_{p t p h}\right)\left(n_{h}\right)=V w_{p d p t}\left(n_{p t}\right)
$$

Where $n_{p t}$ is the total number of plants in the plantation, $n_{p t p h}$ is the number of plants per hectare and $n_{h}$ is te number of hectares covered by the plantation. Then,

$$
\begin{gathered}
V w_{p d P}=300.8(130)(1.04)=300.8(136)= \\
40560 \text { liters } / \text { day } .
\end{gathered}
$$

So, a daily volume of water required for the irrigation of the 1.2 hectares oil palm plantation is 40908.8 liters/day or $40.9088 \mathrm{~m}^{3} /$ day which is approximately $41 \mathrm{~m}^{3} /$ day. Since the irrigation water is pumped from the river to a storage tank, the volume of the water tank must be greater or equal to the daily water volume requirement for the plantation.

\section{The River to Storage Tank Parameters}

The river and storage tank parameters used in the study are as follows;

1. The river level depth is $7 \mathrm{~m}$ and the pump depth is 15 $\mathrm{m}$

2. The storage tank volume is $68.88 \mathrm{~m}^{3}$, the tank diameter is $5.0 \mathrm{~m}$, the tank water full height is 3.51 $\mathrm{m}$ and the tank feeding attitude is $5.0 \mathrm{~m}$.

Figure 3 shows how the river and storage tank parameters are captured in the PVSysts software used for the solar pump system simulation.

\section{The Hydraulic Circuit Parameters}

- The hydraulic circuit parameters used in the study are ;

- Pipe category : PE20(3/4”)

- $\quad$ The piping length: $200 \mathrm{~m}$

- The number of elbows in the piping system:1

- The other friction losses in the pipe: 0.05 .

Figure 4 shows the hydraulic circuit parameters and the schematic diagram of the river-to- storage pumping system.

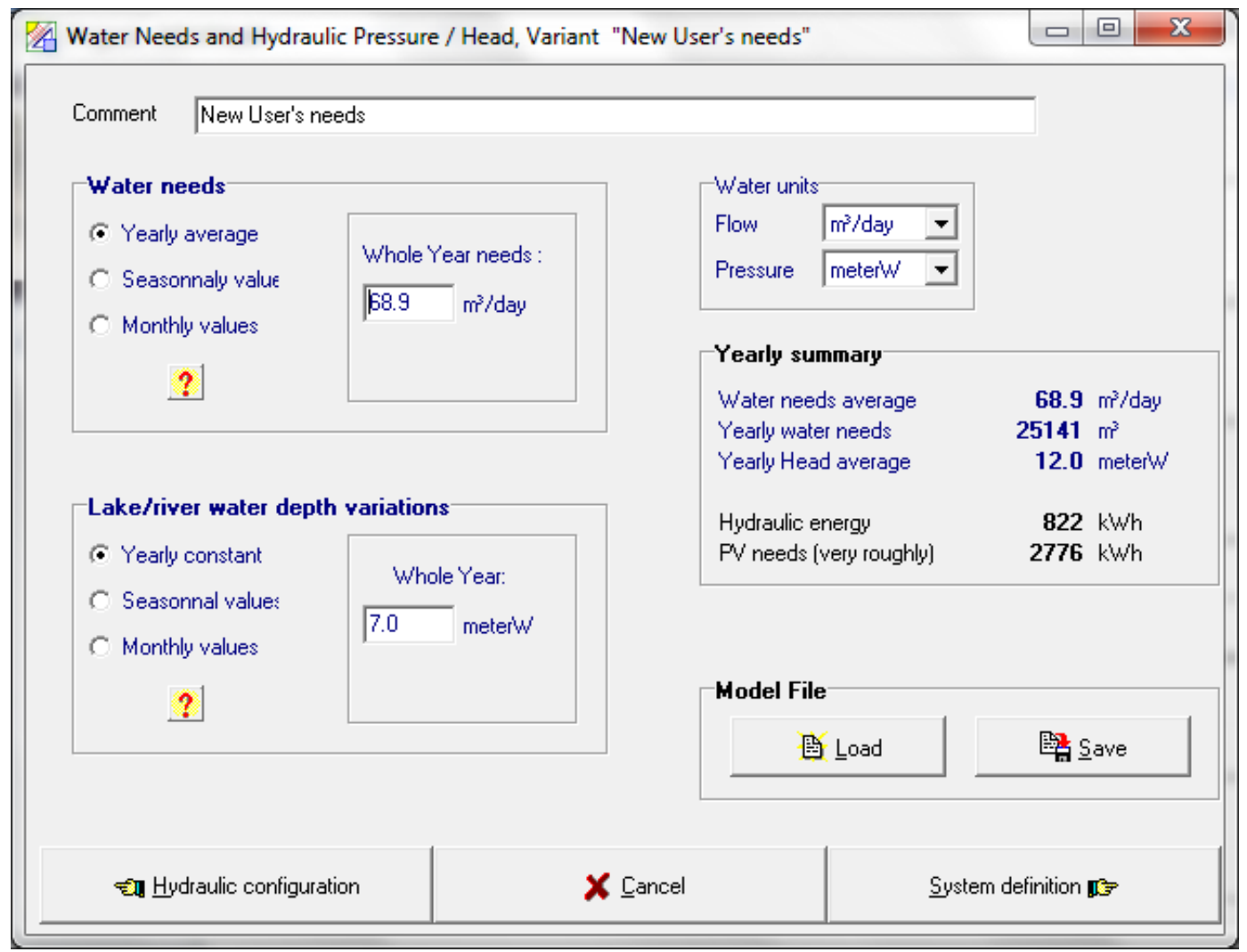

Figure 3. The river and storage tank parameters captured in PVSysts for the solar pump system simulation 


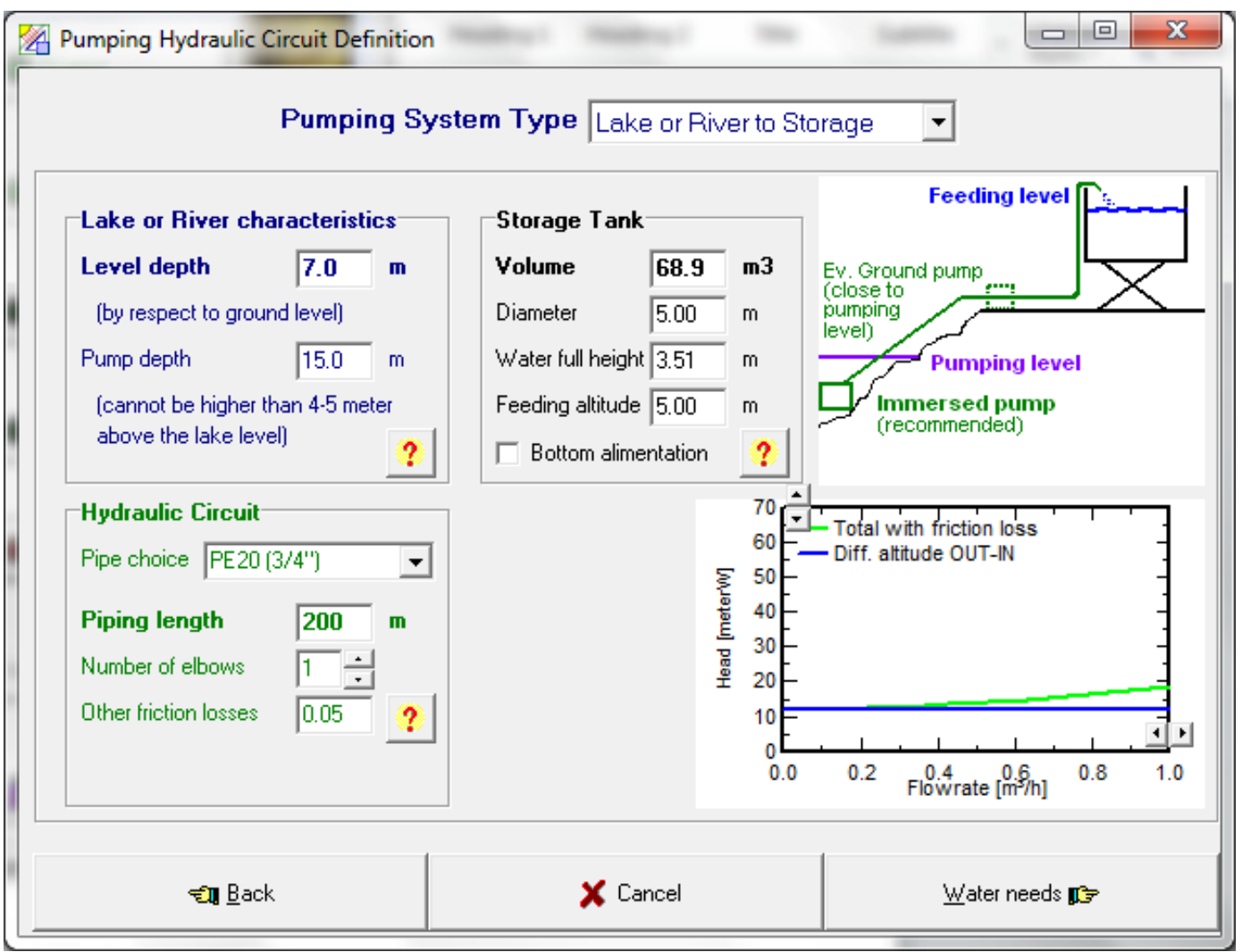

Figure 4. The hydraulic circuit parameters and the schematic diagram of the river-to- storage pumping system

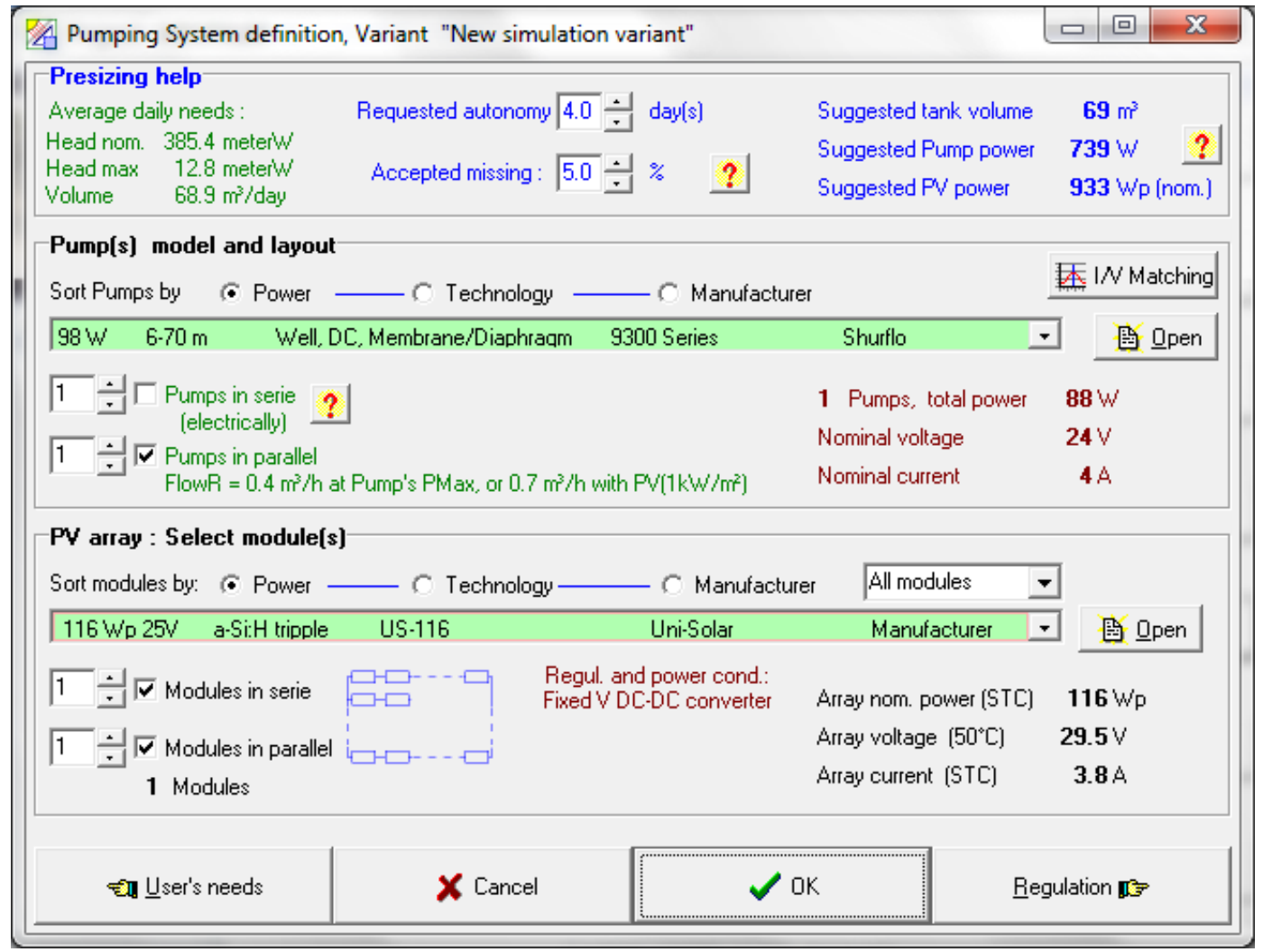

Figure 5. The selected solar pump and solar PV array for the solar pumping system 


\section{The Solar Pump and Solar Panel Selection}

PVSyst software has a database of solar pumps and solar panels that designers can select from and the software provides assistance in the choice of suitable pump and solar PV array for a given user water needs and other system requirements. So, with the help of the PVSyst software suitable pump and solar PV array are selected as shown in Figure 5. The selected pump parameters are;

- $\quad$ Pump Manufacturer: Dankoff

- $\quad$ Pump Model: Centrifugal 7210-36PV

- $\quad$ Pump type $=$ DC motor

- $\quad$ Pump power $=450 \mathrm{~W}$

- $\quad$ Pumping water head 4-17 m

The details of the Pump parameters on PVSyst are shown in Figure 6. Again, the selected PV module parameters are;

- $\quad$ PV Manufacturer: Avancis

- PV Model: Powermax 130W

- $\quad$ PV technology = Copper Indium Selenide (CIS)

- $\quad$ PV power $=130 \mathrm{~W}$

- $\quad$ Number of modules in series $=1$

- $\quad$ Number of modules in parallel $=26$

- $\quad$ Number of pump = 2

- $\quad$ The details of the PV module on PVSyst are shown in Figure 7. Also, the fixed DC-DC converter is selected as the regulator and power conditioning device for the solar pumping system. Furthermore, the schematic circuit diagram of the solar power system with the PV array, the DC converter, the pump and the river-to-storage tank components is shown in Figure 8.

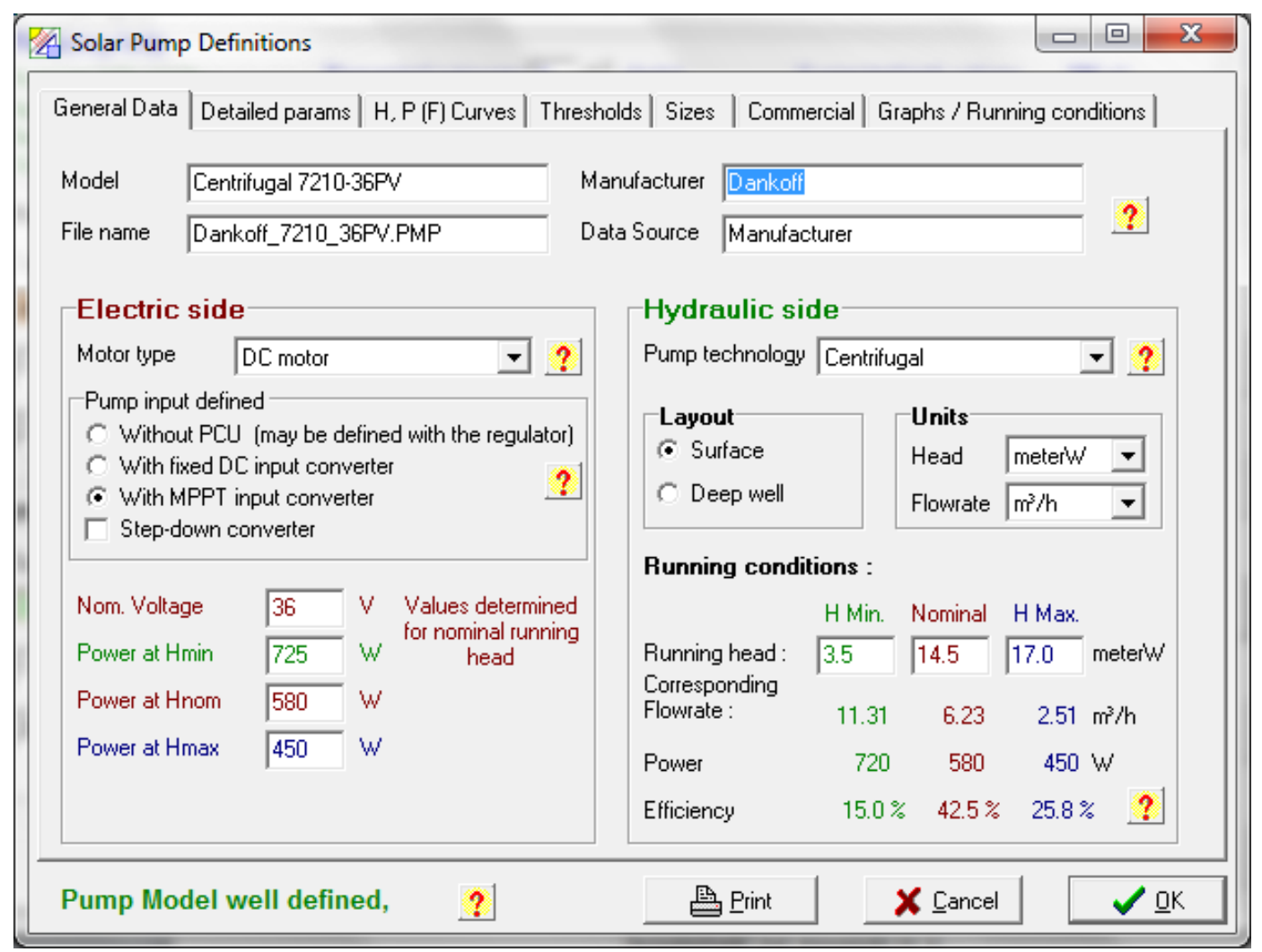

Figure 6. The PVSyst Detail specification of the selected pump 


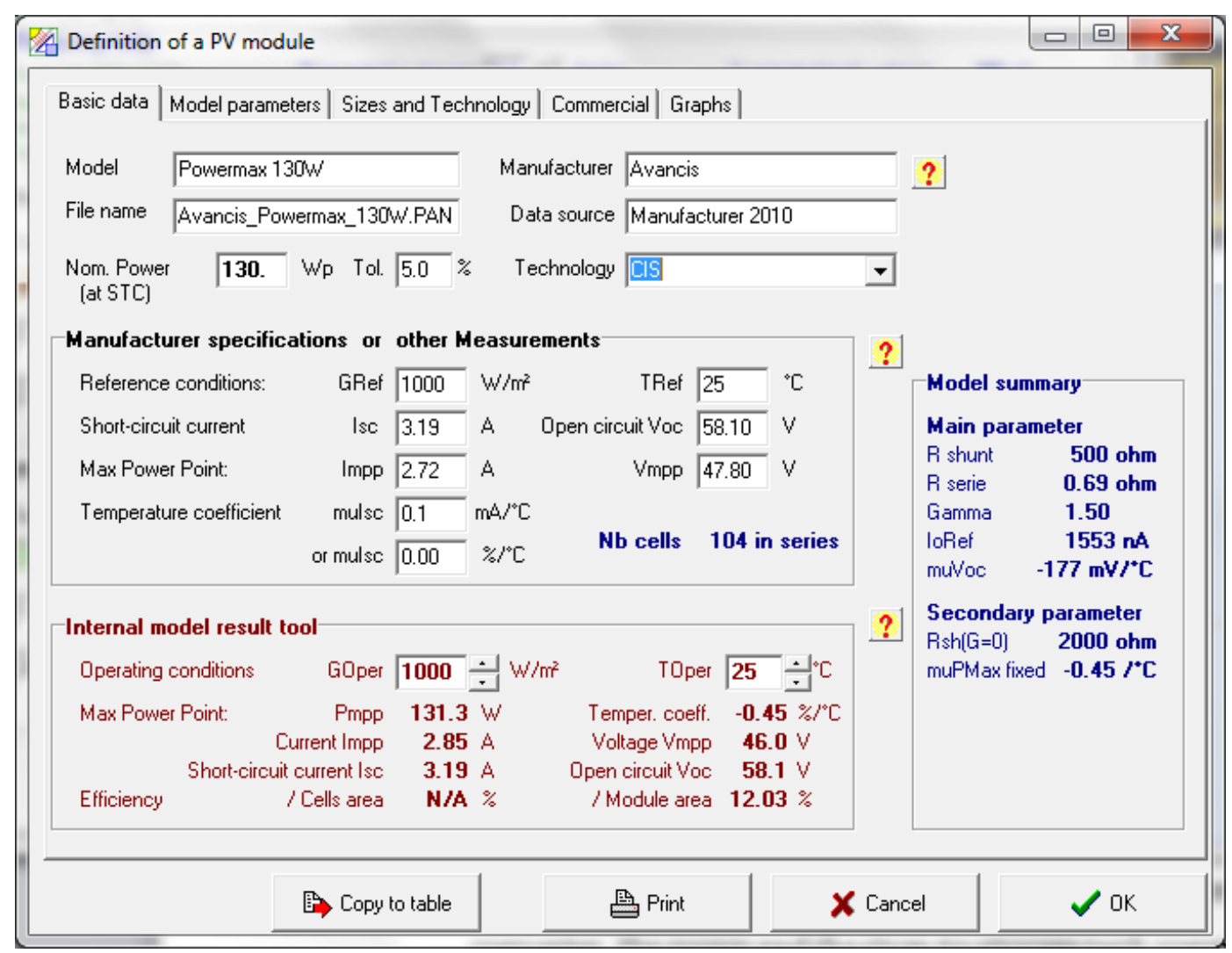

Figure 7. The PVSyst Detail specification of the selected PV Module

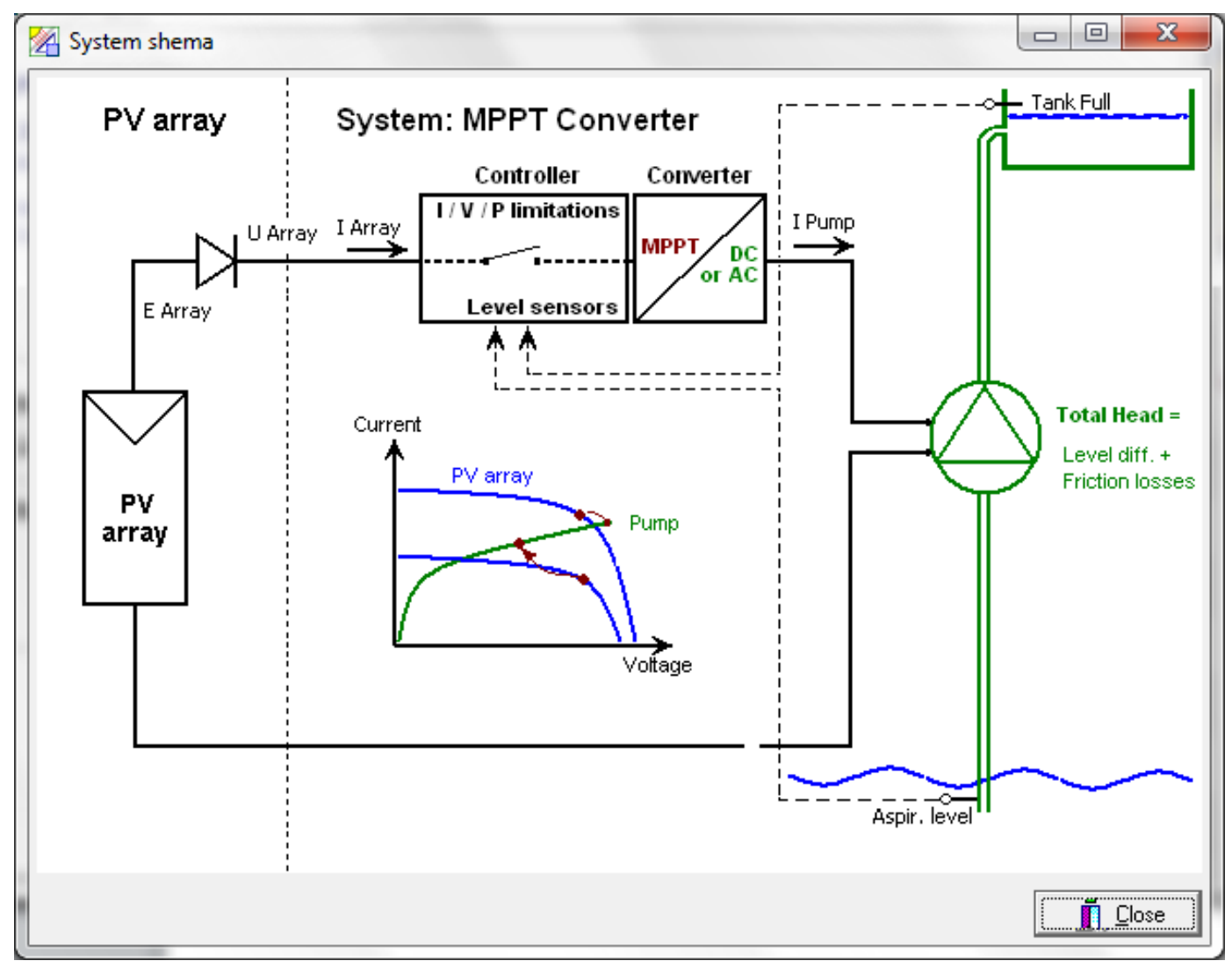

Figure 8. The schematic circuit diagram of the solar power system with the PV array, the MPPT Controller, the pump and the river-to-storage tank components 


\section{Results and Discussions}

The pumping system is simulated in PVSyst software. The summary of the main results for the PV-powered pumping system is shown in Figure 9. According to the results, the annual water demand for the palm plantation is $14636 \mathrm{~m}^{3}$ but the pumping system is able to supply about $12251 \mathrm{~m}^{3}$ which gives a missing water (needed water not supplied ) of about $16.3 \%$ The missing water is computed as follows;

Missing water $(\%)=100\left(\frac{14636-12251}{14636}\right) \%=16.3 \%$ per year
Missing water $\left(\mathrm{m}^{3}\right)=14636-12251=2385 \mathrm{~m}^{3}$ per year

Table 1 shows among other things, the monthly distribution of the pumped water and the missing water. According to Table 1, the months of June to September have missing water above $10 \%$ whereas the months of November to December, as well as January and March, have missing water less than $3 \%$. The consideration here is to determine the month with the critical minimum effective water supply to the palm trees. In view of this, the rain or precipitation data for the case study site is provided in Table 2.

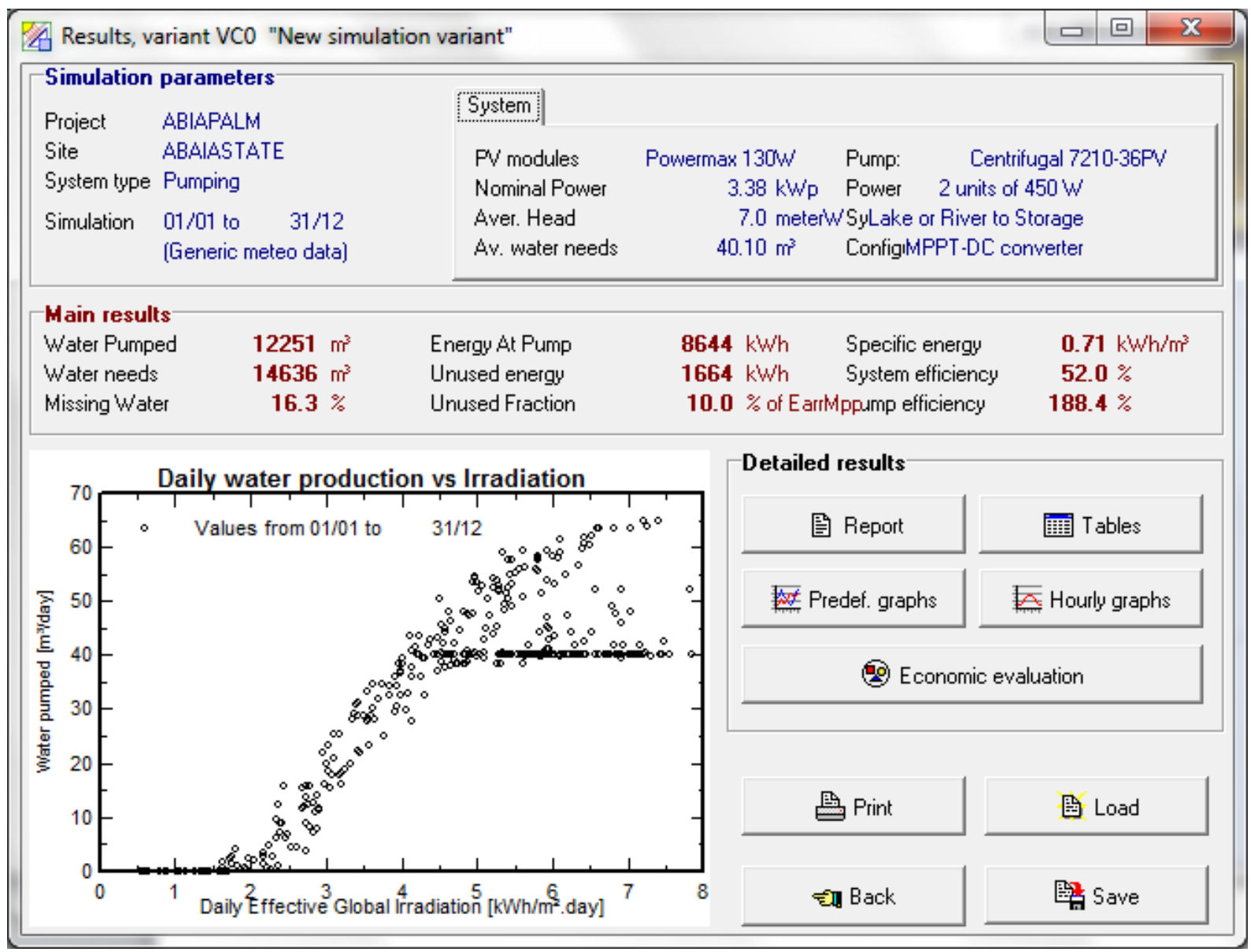

Figure 9. The Main Result Summary For The PV-Powered Pumping System 
Table 1. The monthly distribution of the pumped water and the missing water.

\begin{tabular}{|c|c|c|c|c|c|c|c|c|}
\hline & $\begin{array}{c}\text { GlobEff } \\
\mathrm{kWh} / \mathrm{m}^{2}\end{array}$ & $\begin{array}{c}\text { EArrMPP } \\
\text { KwH }\end{array}$ & $\begin{array}{c}\text { E PmpOp } \\
\text { KwH }\end{array}$ & $\begin{array}{c}\text { ETkFull } \\
\text { KwH }\end{array}$ & $\begin{array}{c}\text { H Pump } \\
\text { meterW }\end{array}$ & $\begin{array}{c}\text { Wpumped } \\
\mathrm{m}^{3} / \text { day }\end{array}$ & $\begin{array}{c}\text { W Used } \\
\mathrm{m}^{3} / \text { day }\end{array}$ & $\begin{array}{c}\text { W Miss } \\
\mathrm{m}^{3} / \text { day }\end{array}$ \\
\hline January & 176 & 483.9 & 229.2 & 74.7 & 127.8 & 39.61 & 39.23 & 0.81 \\
\hline February & 157.8 & 428.1 & 182.9 & 69.78 & 128.4 & 34.94 & 34.94 & 5.16 \\
\hline March & 160.4 & 443.5 & 225.6 & 58.87 & 122.3 & 38.06 & 38.27 & 1.83 \\
\hline April & 144.8 & 399.8 & 206.1 & 40.27 & 122.7 & 36.03 & 36.01 & 4.09 \\
\hline May & 135.6 & 375.9 & 213.6 & 27.31 & 116.3 & 34.83 & 34.65 & 5.45 \\
\hline June & 119.3 & 330.1 & 181.7 & 21.67 & 108.3 & 29.2 & 29.55 & 10.55 \\
\hline July & 111.5 & 309.5 & 186.5 & 4.22 & 103.3 & 28.26 & 29.10 & 11.00 \\
\hline August & 110.0 & 304.1 & 173.3 & 10.18 & 109.6 & 27.19 & 27.19 & 12.91 \\
\hline September & 113.8 & 314.9 & 166.4 & 21.92 & 110.9 & 27.07 & 25.87 & 14.23 \\
\hline October & 129.8 & 360.7 & 196.4 & 23.61 & 119.2 & 32.49 & 32.52 & 7.58 \\
\hline November & 146.7 & 404.0 & 215.5 & 42.81 & 118.3 & 36.66 & 37.15 & 2.95 \\
\hline December & 169.5 & 467.2 & 223.9 & 66.94 & 126.5 & 38.4 & 37.87 & 2.23 \\
\hline Year & 1675.3 & 4621.6 & 2401.2 & 462.3 & 118.2 & 33.57 & 33.53 & 6.57 \\
\hline
\end{tabular}

Table 2. Years-Monthly Average precipitation for the case study site located at a latitude of 5.84 and a longitude of 7. 48

\begin{tabular}{|c|c|c|c|c|c|c|c|c|c|c|c|c|c|}
\hline Month & JAN & FEB & MAR & APR & MAY & JUN & JUL & AUG & SEP & OCT & NOV & DEC & ANNUAL \\
\hline $\begin{array}{c}\text { Average precipitation } \\
\text { (mm/day) }\end{array}$ & 0.45 & 1.05 & 2.76 & 5.12 & 6.69 & 8.82 & 8.11 & 8.36 & 10.03 & 8.66 & 2.34 & 0.57 & 5.26 \\
\hline
\end{tabular}

Source : NASA website : https://power.larc.nasa.gov/data-access-viewer/; Accessed on 20 /11/2018)

The effective water supply to the plant is a combination of the water supplied by the rainwater and by the irrigation system. As such, it is seen that the months of June to October have their precipitation values above $8 \mathrm{~mm}$ per day whereas the months of November to December, as well as January to March, have values below $3 \mathrm{~mm}$ per day. Besides, these months with low precipitation values are in the dry season. As such, there is an abundance of rainwater to make up for the shortfalls in the irrigation water supply for the months of April to October. The critical month in terms of effective water supply to the plants is the February with precipitation value of $1 \mathrm{~mm}$ per day and missing water value of $5.6 \%$. Consequently, the actual water supplied by the irrigation system per palm tree in the February need to be evaluated to determine if additional water supply will be needed.

According to the design specifications, there are about 136 palm trees in the 1.04 hectares of palm plantation. The February daily water supply of $34.94 \mathrm{~m}^{3}$ gives 34940 liters per day. Since the plantation is a mixture of the grown-up yielding oil palm trees and the older oil palm trees, it is assumed in this paper that there is a distribution of $60 \%$ grown-up yielding oil palm trees and $40 \%$ older oil palm trees in the plantation. Again, it has been stated that the grown-up yielding oil palm tree of three (3) years and above require about 150-200 liters of water per day. Hence, if 200 liters/day is assumed, the water consumed by the grown-up yielding oil palm trees per day is given as;

Water consumed by the grown-up yielding oil palm trees per day $=\left(\frac{60}{100}\right)(136)(200)=16320$ liters/day.

The total number of the older palm tree is $\left(\frac{40}{100}\right)(136)=54.5 \approx 55$. The water available for the 55 older palm trees per day is $34940-16320=18620$ liters/day which gives 338.55 liters/day. This value is above the minimum hot weather daily water requirement of the older palm trees. Besides, February still has precipitation value of about $1.05 \mathrm{~mm}$ per day. Hence, the rainwater in the month of February will supply any further water required by the older palm trees.

The loss diagram of the solar pumping system is given in Figure 9. The loss diagram shows that the average annual solar radiation on the horizontal plane is $1717 \mathrm{Kwm} / \mathrm{m}^{2}$, but a transposition gain on the tilted plane of $1 \%$ and the IAM loss of $-3.4 \%$ give a net loss of $-2.4 \%$ and an effective annual average daily solar radiation of 1675 $\mathrm{Kwm} / \mathrm{m}^{2}$ on the tilted plane (as shown in Figure 9 and in column 2 of Table 1). Then, with a total PV array area of 28 $\mathrm{m}^{2}$ and module efficiency of $12 \%$, the PV array produced an annual average daily energy of $5718.5 \mathrm{Kwh}$ (as shown in Figure 9). Losses in the PV array, the pump and in the other components of the system reduced the total energy to $2401 \mathrm{Kwh}$ operating energy at the pump (as shown in Figure 9 and in column 2 of Table 1). Finaly, the effective energy of $2401 \mathrm{Kwh}$ is $41 \%$ of the $5718.5 \mathrm{Kwh}$ produced at the PV array output, as shown in Figure 10 and Figure 11. 


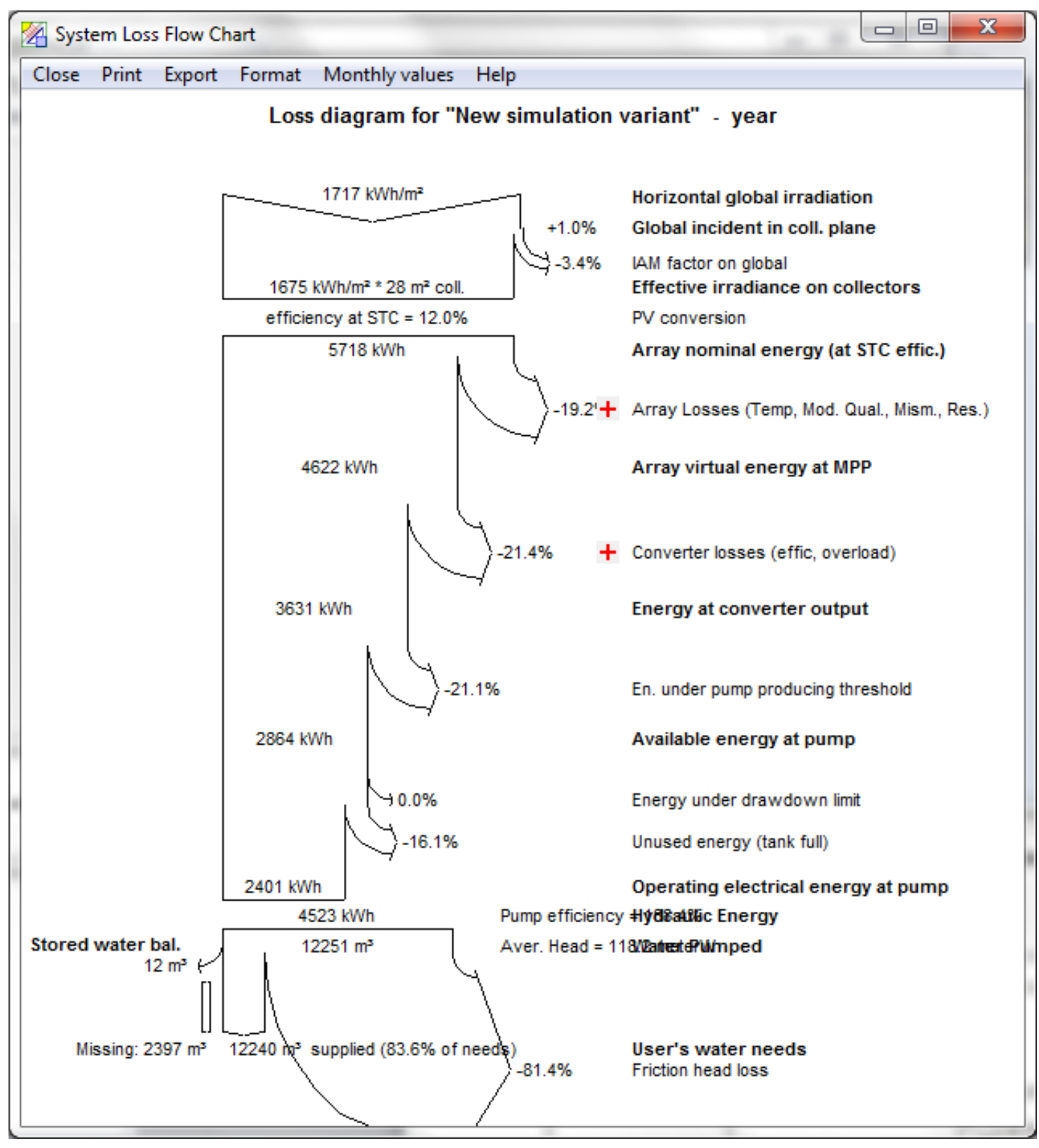

Figure 10. The Loss Diagram of the Solar Pumping System 


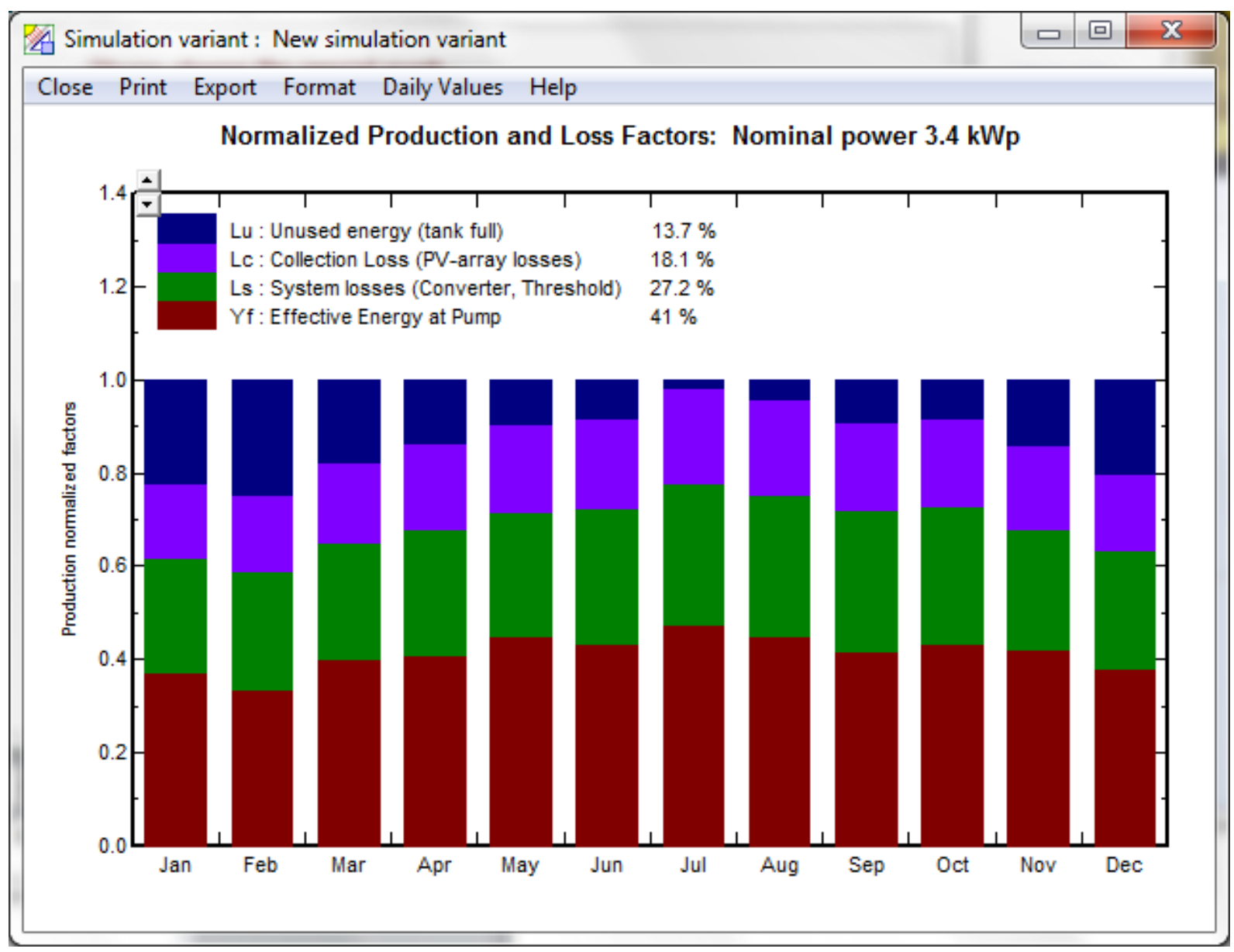

Figure 11. The normalised production and loss factor

\section{Conclusions}

Solar powered pump for irrigation of an oil palm plantation was presented. The drip irrigation system was used and the requisite daily water requirement for the palm trees was computed. Then PVSyst software was used to simulate the river-to-storage solar-powered pump for the irrigation system. February was identified as the critical month. The losses in the system were also determined. In all, the pumping system is able to supply the required water for all the months especially when the rainwater capture in the case study site was also considered.

\section{REFERENCES}

[1] Coban, F., Ozer, H., Ors, S., Sahin, U., Yildiz, G., \& Cakmakci, T. (2018). Effects of deficit irrigation on essential oil composition and yield of fennel (Foeniculum vulgare Mill) in a high-altitude environment. Journal of Essential Oil Research, 30(6), 457-463.

[2] Morshedloo, M. R., Craker, L. E., Salami, A., Nazeri, V., Sang, H., \& Maggi, F. (2017). Effect of prolonged water stress on essential oil content, compositions and gene expression patterns of mono-and sesquiterpene synthesis in two oregano (Origanum vulgare L.) subspecies. Plant Physiology and Biochemistry, 111, 119-128.

[3] Blok, C., van Os, E., Daoud, R., Waked, L., \& Hasan, A. (2017). Hydroponic Green Farming Initiative: increasing water use efficiency by use of hydroponic cultivation methods in Jordan (No. 1447). Wageningen University \& Research, BU Greenhouse Horticulture.

[4] Uchida, R. (2000). Essential nutrients for plant growth: nutrient functions and deficiency symptoms. Plant nutrient management in Hawaii’s soils, 31-55.

[5] Morison, J. I. L., Baker, N. R., Mullineaux, P. M., \& Davies, W. J. (2008). Improving water use in crop production. Philosophical Transactions of the Royal Society of London B: Biological Sciences, 363(1491), 639-658.

[6] Coban, F., Ozer, H., Ors, S., Sahin, U., Yildiz, G., \& Cakmakci, T. (2018). Effects of deficit irrigation on essential oil composition and yield of fennel (Foeniculum vulgare Mill) in a high-altitude environment. Journal of Essential Oil Research, 30(6), 457-463

[7] Dada, M., Nwawe, C. N., Okere, R. A., \& Uwubanmwen, I. O. (2012). Potentials of date palm tree to the Nigerian economy. World Journal of Agricultural Sciences, 8(3), 309-315.

[8] Dhehibi, B., Salah, M. B., Frija, A., Aw-Hassan, A., El 
Ouhibi, H., \& Al Raisi, Y. M. (2018). Economic and Technical Evaluation of Different Irrigation Systems for Date Palm Farming System in the GCC Countries, Case of Oman.

[9] Bourziza, R., Hammani, A., Mailhol, J. C., Bouaziz, A., \& Kuper, M. (2017). Modeling subsurface drip irrigation for date palm under oasis conditions. CAHIERS AGRICULTURES, 26(3).

[10] Peterson, C. A., Soares, T., Torbert, E., Herrera, I., Scow, K. M., \& Gaudin, A. C. (2016, January). Drip irrigation effect on soil function, root systems and productivity in organic tomato and corn. In Proceedings of the Organic Agriculture Research Symposium Pacific Grove, CA.

[11] Qian, J., Horn, H., Tarchitzky, J., Chen, Y., Katz, S., \& Wagner, M. (2017). Water quality and daily temperature cycle affect biofilm formation in drip irrigation devices revealed by optical coherence tomography. Biofouling, 33(3), 211-221.

[12] NASA (2018) POWER DATA ACCESS VIEWER online free tool. Available at: https://power.larc.nasa.gov/data-acc ess-viewer/ Accessed on 10th November 2018

[13] Barcelos, E., Rios, S. D. A., Cunha, R. N., Lopes, R., Motoike, S. Y., Babiychuk, E., ... \& Kushnir, S. (2015). Oil palm natural diversity and the potential for yield improvement. Frontiers in plant science, 6, 190.

[14] Ukwuteno, S. O. (2011). Economics of Small-scale Oil Palm Production in Kogi State, Nigeria. A Ph. D Thesis Presented to the Dept of Agricultural Economics, University of Nigeria, Nsukka, Nigeria. Available at :http://www.unn.edu.ng/publi cations/files/images/Ukwuteno\%20S.O.\%20Ph.pdf Accessed 6th November 2018

[15] Hartley C.W.S. (1988). The Origin and Development of the Oil Palm Industry in The Oil Palm (Elaeis guineensis Jacq) 3rd Edition. Pp. 1-43

[16] Osbert H. (2012) Promotion Of Oil Palms: A Case Of Tenera Oil Palms In Isubilo, Mwense-Luapula Zambia Master Degree research thesis at Van Hall Larenstein, University of Applied Sciences Wageningen, Netherlands Available at : http://edepot.wur.nl/298454 Accessed 6th November 2018

[17] MRUDULA, B. (2012). Economic Analysis of Drip Irrigation in Oil palm Cultivation in East Godavari District of Andhra Pradesh (Doctoral dissertation, ACHARYA NG RANGA AGRICULTURAL UNIVERSITY). Available at http://krishikosh.egranth.ac.in/bitstream/1/67587/1/D9381. pdf

[18] NaanDanJain (2011) Oil Palm. A technical paper Available at:http://www.naandanjain.com/uploads/catalogerfiles/oil-p alm-2/NDJ_OilPlam_booklet_eng_240314F_72.pdf

[19] Aridah, A. M. A. (2016). Effect of Type of Irrigation System on Productivity and Income of Date Palm Growers in Sebha, Libya (Doctoral dissertation, Curtin University)

[20] Mrudula, B. (2012). Economic Analysis of Drip Irrigation in Oil palm Cultivation in East Godavari District of Andhra Pradesh. A master thesis, at Acharya Ng Ranga Agricultural University, Andhra Pradesh, Indian. Available at: https://www.google.com/search?client=firefox-b-ab\&q=Oil + palm+requires+adequate+irrigation $\% 2 \mathrm{C}+\mathrm{as}+\mathrm{it}+\mathrm{is}+\mathrm{a}+\mathrm{fast}$ +growing+crop+pdf. Accessed on 13th November 2018.
[21] Netafim "Oil Palm” A technical paper of Netafim irrigation India PVT. LTD. Available at: https://www.netafimindia.c om/wp-content/uploads/2014/12/OIL-PALM.pdf. Accessed on 10th of November 2018. 